\title{
Meningkatkan Hasil Belajar Tema Sumber Energi Melalui Model Pembelajaran Make A Match Siswa Kelas IV SD Inpres Pancana Kabupaten Barru
}

\author{
Hasnah
}

Guru SD Inpres Pancana, Kabupaten Barru, Sulawesi Selatan

\begin{abstract}
Abstrak
Tes diagnosis akhir pertemuan awal pembelajaran semester 1 tahun pelajaran 2017-2018, hasil belajar yang dicapai belum mencapai standar kualitas rerata minimal 70 atau kategori cukup, dengan tuntas belajar 71,0\% klasikal yang mencapai nilai KKM 70, rata-rata hasil belajar yang dicapai siswa 64,57 tuntas belajar 42,86\% dari frekeunsi siswa yang tuntas belajar 3 orang dari total jumlah siswa 7 orang. Kemampuan guru dan aktivitas belajar siswa dalam melaksanakan pembelajaran tidak mencapai standar lebih besar $62,5 \%$ atau minimal baik, skor persentase kemampuan guru yang dicapai hanya 50,93\% kategori cukup, aktivitas belajar siswa hanya 52,78\% kategori cukup. (Hasnah, 2017). Sulusi penyelesaian masalah tersebut, mengambil inisiatif dengan melaksanakan model pembelajaran Make A Match pada pembelajaran tema sumber energi. Penelitian tindakan kelas ini berdaur ulang tahapan siklus. Setiap siklus diilaksanakan empat tahap, yaitu 1) Perencanaan tindakan, 2) Pelaksanaan tindakan, 3) Observasi, dan 4) Refleksi. Setiap siklus terdiri tiga kali pertemuan pemberian tindakan kemudian diberikan tes akhir siklus. Subjek dalam penelitian ini siswa kelas IV SD Inpres Pancana yang berjumlah 7 orang siswa, yaitu 4 orang perempuan dan 3 orang laki-laki. Data kuantitatif dikumpul melalui lembar tes hasil belajar tema organ gerak hewan tiap akhir siklus. Data kualitatif dikumpul melalui lembar observasi aktivitas belajar siswa dan kemampuan guru. Hasil penelitian menunjukkan bahwa: (1) Hasil belajar peserta didik meningkat skor rerata selisih 11,43\%, meningkat kategori kurang menjadi cukup siklus 3 dari siklus 2, dengan tuntas belajar 5 orang total siswa 7 orang dengan persentase $71,4 \%$, menunjukkan minimal 70 atau minimal kategori cukup. (2) Kemampuan guru meningkat skor persentase selisih $23,15 \%$ dan kategori baik siklus 3 dari cukup siklus 2. (3) Aktivitas peserta didik meningkat skor persentase selisih 17,72\% dan kategori baik siklus 3 dari cukup siklus 2 .
\end{abstract}

Kata Kunci: hasil belajar, sumber energi, make a match

\section{Pendahuluan}

Menurut hasil tes diagnosis akhir pertemuan pembelajaran awal semester 1 tahun pelajaran 2017-2018, hasil belajar yang dicapai belum mencapai standar kualitas rerata minimal 70 atau kategori cukup, dengan tuntas belajar $71,0 \%$ klasikal yang mencapai nilai KKM 70, rata-rata hasil belajar yang dicapai siswa 64,57 tuntas belajar 42,86\% dari frekeunsi siswa yang tuntas belajar 3 orang dari total jumlah siswa 7 orang. Kemampuan guru dan aktivitas belajar siswa dalam melaksanakan pembelajaran tidak mencapai standar lebih besar $62,5 \%$ atau minimal baik, skor persentase kemampuan guru yang dicapai hanya 50,93\% kategori cukup, aktivitas belajar siswa hanya 52,78\% kategori cukup. (Hasnah, 2017).

Hasil belajar adalah perubahan perilaku yang diperoleh siswa setelah mengalami aktivitas belajar (Catharina. 2004: 4). Disimpulkan, hasil belajar adalah hasil yang diperoleh 
siswa setelah melakukan suatu kegiatan belajar dalam waktu tertentu. Misalnya hasil belajar yang diperoleh setelah melakukan kegiatan belajar setiap siklus. Hasil belajar dapat dilihat setelah diberikan tindakan dan diberikan tes.

Sumber energi marupakan bagian materi pembelajaran sub tema 2 selalu berhemat energi, terdiri 3 sub tema yaitu: Sub tema 1 sumber energi, sub tema 2 manfaat energi, sub tema 3 energi alternatif. Sedangkan yang dibahas dalam penelitian ini adalah sub tema 1 sumber energi. (Kementerian Pendidikan dan Kebudayaan, 2017: 1-9).

Model Make a Match atau mencari pasangan merupakan salah satu alternatif yang dapat diterapkan kepada siswa. Penerapan metode ini dimulai dari teknik yaitu siswa disuruh mencari pasangan kartu yang merupakan jawaban/soal sebelum batas waktunya, siswa yang dapat mencocokkan kartunya diberi poin. Teknik metode pembelajaran Make a Match atau mencari pasangan dikembangkan oleh Lorna Curran. Salah satu keunggulan tehnik ini adalah siswa mencari pasangan sambil belajar mengenai suatu konsep atau topik dalam suasana yang menyenangkan (Rusman, 2012: 223).

Disimpulkan langkah-langkah model pembelajaran Make a Matchyang digunakan dalam penelitian ini adalah: (1) Guru menyiapkan beberapa kartu yang berisi beberapa konsep atau topik yang cocok untuk sesi review, satu bagian kartu soal dan bagian lainnya kartu jawaban. (2) Setiap siswa mendapatkan sebuah kartu yang bertuliskan soal/ jawaban. (3) Tiap siswa memikirkan jawaban/soal dari kartu yang dipegang (4) Setiap siswa mencari pasangan kartu yang cocok dengan kartunya. (5) Setiap siswa yang dapat mencocokkan kartunya sebelum batas waktu diberi poin. (6) Jika siswa tidak dapat mencocokkan kartunya dengan kartu temannya (tidak dapat menemukan kartu soal atau kartu jawaban) akan mendapatkan hukuman, yang telah disepakati bersama. (7) Setelah satu babak, kartu dikocok lagi agar tiap siswa mendapat kartu yang berbeda dari sebelumnya, demikian seterusnya. (8) Siswa juga bisa bergabung dengan 2 atau 3 siswa lainnya yang memegang kartu yang cocok. (9) Guru bersama-sama dengan siswa membuat kesimpulan terhadap materi pelajaran.

\section{Metode}

Penelitian tindakan kelas ini berdaur ulang tahapan siklus. Setiap siklus diilaksanakan empat tahap, yaitu 1) Perencanaan tindakan, 2) Pelaksanaan tindakan, 3) Observasi, dan 4) Refleksi (Suharsimi, 2007: 16). Setiap siklus terdiri tiga kali pertemuan pemberian tindakan kemudian diberikan tes akhir siklus. Subjek dalam penelitian ini siswa kelas IV SD Inpres Pancana yang berjumlah 7 orang siswa, yaitu 4 orang perempuan dan 3 orang laki-laki. Data kuantitatif dikumpul melalui lembar tes hasil belajar tema organ gerak hewan tiap akhir siklus. Data kualitatif dikumpul melalui lembar observasi aktivitas belajar siswa dan kemampuan guru.

Instrumen dalam mengumpulkan data: (1) Observasi adalah kegiatan pengumpulan data dengan berkunjung langsung ke objek yang akan diteliti, kemudian mencatat data-data yang dibutuhkan. Sedangkan teknik pengumpulan data dengan observasi digunakan bila peneliti berkenaan dengan perilaku manusia, proses kerja, gejala-gejala alam, dan bila responden yang diamati tidak terlalu besar (Sugiyono, 2016: 203). Observasi dalam penelitian ini adalah observasi terstruktur/sistematis, kemampuan guru dan aktivitas belajar peserta didik. (2) Metode dokumentasi digunakan untuk memperoleh data tentang keadaan siswa kelas IV SD Inpres Pancana kabupaten Barru terdiri 7 orang peserta didik, yang meliputi: Nama siswa, 
nomor induk siswa, dan nilai hasil tes diagnosis hasil belajar dari tema sumber energi semester I tahun pelajaran 2017-2018 (3) Jurnal, jurnal adalah catatan harian (Departemen Pendidikan Nasional, 2008: 549). Pencatatan yang dilakukan mengenai tingkat kahadiran peserta didik dalam melaksanakan tindakan dan tes, kebersihan lingkungan kelas, serta kondisi yang dibuat siswa pada saat tindakan berlangsung. (4) Tes subjektif berbentuk uraian (essai). Bentuk tes essai butir soal yang mengandung pertanyaan atau tugas yang jawaban atau mengerjakan soal tersebut harus dilakukan dengan cara mengekspresikan pikiran peserta tes. (Asmawi Zaenul \& Noehi Nasution, 2005: 37 dalam Widoyoko, 2012: 82-83). Tes untuk mengukur hasil belajar adalah tes essai.

Teknik analisa data kuantitatif hasil belajar secara deskriptif dengan menggunakan program SPSS Version -20. Teknik analisa data kualitatif kemampuan guru dan aktivitas peserta didik adalah dilakukan setelah pengumpulan data, dengan tahap kegiatanyaitu: Mereduksi data, menyajikan data, dan penarikan kesimpulan atau verifikasi (Milles \& Huberman, 1992).

Standarisasi kualitas penerimaan keberhasilan tindakan adalah: (1) Keberhasilan penelitian hasil belajar tema sumber energi, terjadi perubahan peningkatan secara positif, bilamana terdapat peningkatan dari siklus ke siklus dengan kualitas kategori siklus terakhir menunjukkan minimal 70 atau minimal kategori cukup, dengan tuntas belajar minimal $71 \%$ yang mendapat nilai KKM 70. (2) Didukung keberhasilan penelitian kemampuan guru dan aktivitas peserta didik, terjadi perubahan secara positif, bila mencapai peningkatan dari siklus ke siklus dengan kualitas persentase dan kategori siklus pada akhir, menunjukkan kualitas lebih besar $62,5 \%$ atau minimal kategori baik. (3) Didukung secara positif kehadiran peserta didik dalam melaksanakan tindakan dan tes, bilamana persentase yang dicapai minimal $71 \%$.

\section{Hasil}

Secara grafik, perkembangan hasil penelitian dari siklus 1 sampai siklus 3, menurut gambar 1 berikut:

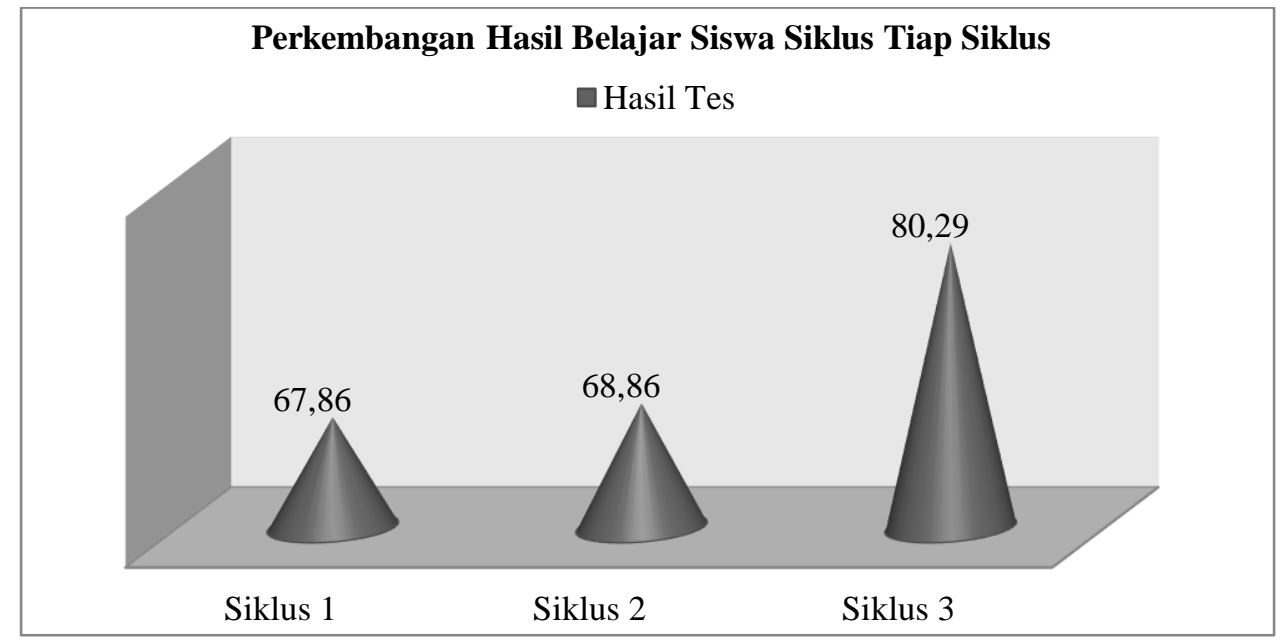

Gambar 1. Grafik perkembangan hasil belajar siklus 1 sampai siklus 3

Secara grafik, perkembangan dukungan kemampuan guru siklus 1 sampai siklus 3, menurut gambar 2 berikut: 


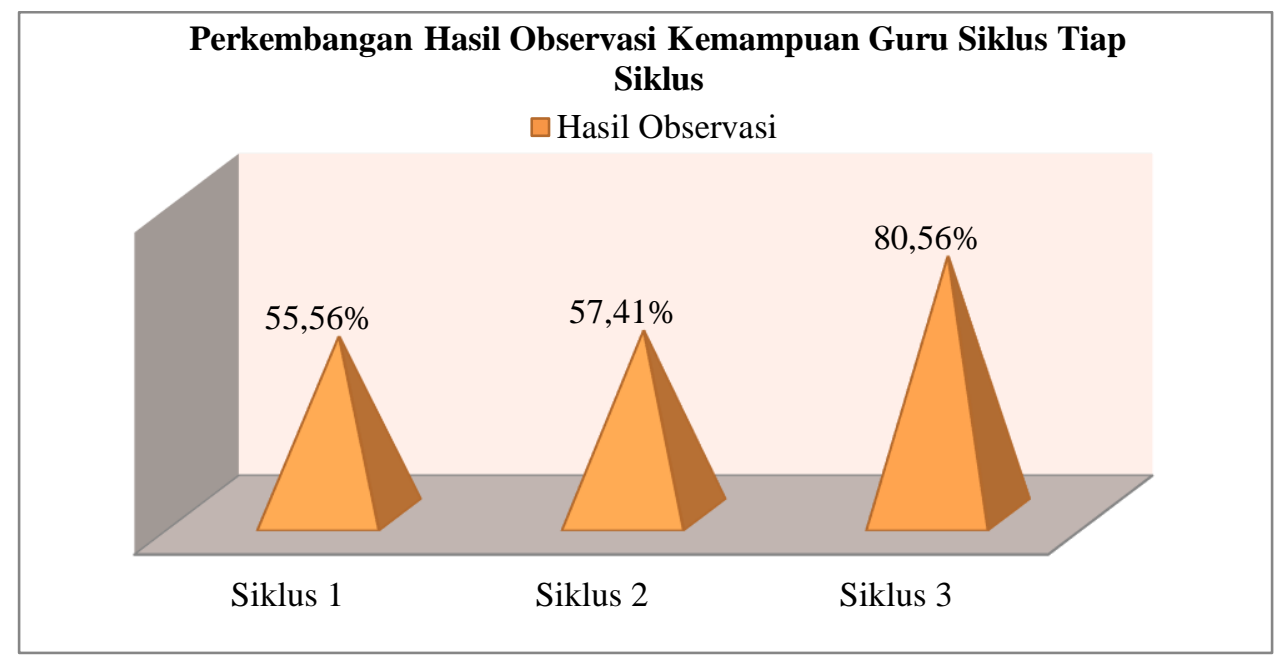

Gambar 2. Grafik perkembangan hasil observasi kemampuan guru siklus I sampai siklus 3

Secara grafik, perkembangan dukungan aktivitas belajar siswa dalam melaksanakan tindakan model pembelajaran Make a Make siklus 1 sampai siklus 3, menurut gambar 3 berikut:

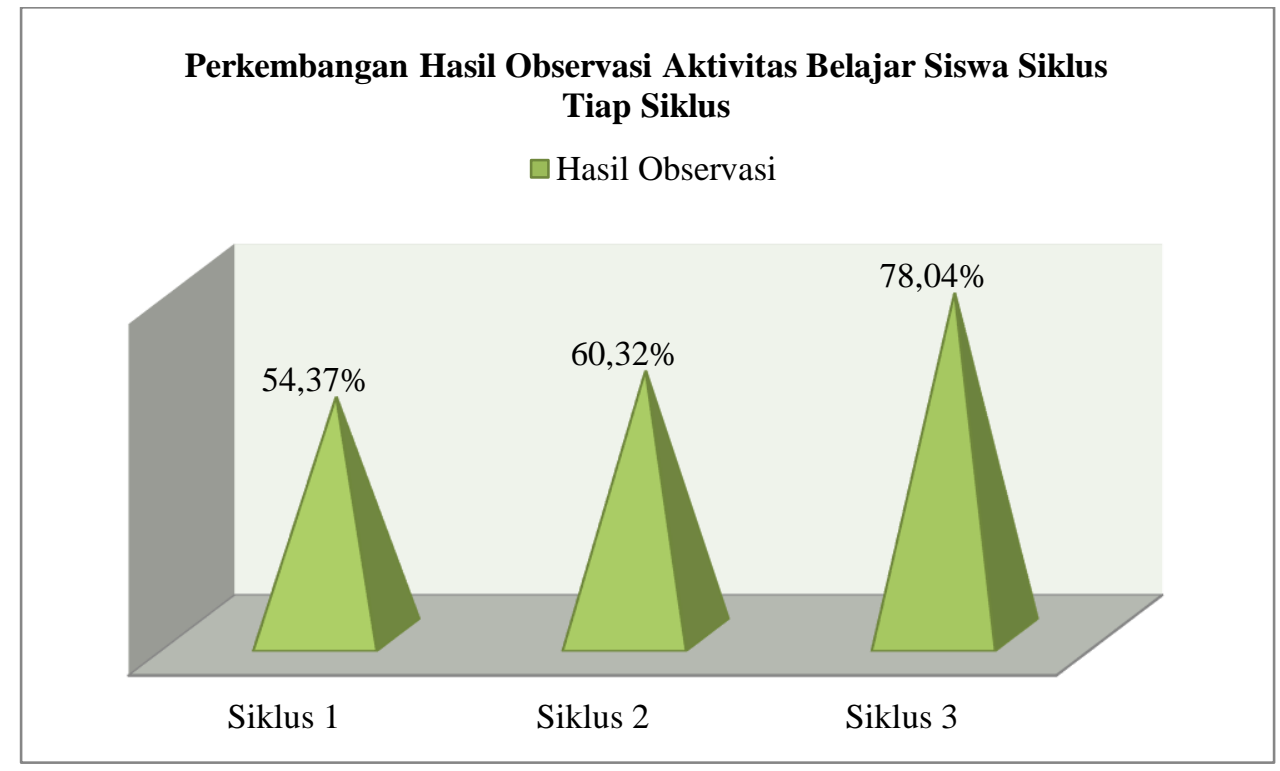

Gambar 3. Grafik perkembangan hasil observasi aktivitas belajar siswa siklus 1 sampai siklus 3.

\section{Pembahasan}

\section{Siklus satu}

Siklus 1, pencapaian hasil belajar tema sumber energi adalah rkor rerata 67,86 kategori kurang, dengan tuntas belajar $57,1 \%$ dari 4 orang subjek dan yang belum tuntas 3 orang subjek $42,9 \%$ dari total subjek 7 orang. Tidak mencapai standar kualitas minimal 70 dengan tuntas belajar klasikal minimal $71,0 \%$ yang mencapai nilai KKM 70, menurut indikator keberhasilan penelitian ini. Jika dibandingkan pra siklus, skor rerata 64,57 kategori kurang, dengan tuntas belajar $42,86 \%$ dari 3 orang subjek dari total subjek 7 orang, meningkat rerata skor selisih 3,29\% kategori tidak meningkat tetap kurang siklus 1 dari pra siklus. Kekurangan hasil belajar di siklus 1 diperbaiki di siklus 2 dengan upaya dibimbing dengan baik dan diberi remedial yang 
belum tuntas 3 orang subjek. Sedangkan kelebihannya adalah 4 orang subjek sudah tuntas belajar dipertahankan agar tidak menurun dan diuoayakan agar dapat meningkat menjadi cukup atau di atas cukup.

Kemampuan guru siklus I adalah jumlah skor nilai yang dicapai 60 dengan 55,56\% kategori cukup, dengan skor total 108, jika dibandingkan pra siklus jumlah skor nilai yang dicapai 55 dengan 50,93\% kategori cukup, dengan skor total 108, terjadi peningkatan selisih 4,63\% kategori tidak meningkat tetap cukup siklus 1 dari pra siklus, belum terjadi perubahan secara positif. Selain itu, masih banyak kekurangan/kelebihan kemampuan guru yang ditemukan siklus 1, diperbaiki di siklus 2 dengan upaya yang dilakukan dengan memaksimalkan dalam menyiapkan beberapa kartu, membimbing setiap siswa mendapatkan sebuah kartu dan mencari pasangan kartu serta mencocokkan kartunya dan yang tidak dapat mencocokkan kartunya dan kartu dikocok lagi agar tiap siswa mendapat kartu yang berbeda dari sebelumnya, membimbing tiap siswa dalam memikirkan jawaban/soal dari kartu yang dipegang. Kelebihannya adalah membimbing siswa dalam bergabung dengan 2 atau 3 siswa lainnya yang memegang kartu yang cocok, kemudian membuat kesimpulan terhadap materi pelajaran sudah baik diusahakan agar tidak menurun dan dapat meningkat menjadi sangat baik (Indah, Suhardi, \& Ramadhana, 2021).

Aktivitas belajar peserta didik siklus 1 adalah jumlah skor nilai yang dicapai 411 dengan $54,37 \%$, dikategorikan cukup, dari total jumlah skor 756 , jika dibandingkan pra siklus, jumlah skor nilai yang dicapai 399 dengan 52,78\%, dikategorikan cukup, dari total jumlah skor 756, meningkat skor persentase selisih 1,59\%, kategori tidak meningkat tetap cukup siklus 1 dari pra siklus, belum terjadi perubahan secara positif, karena mencapai peningkatan skor persentase tetapi kategori tetap cukup dari pra siklus ke siklus 1, dengan kualitas persentase dan kategori siklus 1 belum menunjukkan kualitas lebih besar 62,5\% atau minimal kategori baik. Masih banyak kekurangan/kelebihan aktivitas belajar peserta didik yang ditemukan siklus 1 diperbaiki di siklus 2, kelebihannya dipertahan supaya tidak menururn dan diupayakan agar dapat menjadi sangat baik.

Refleksi tingkat kehadiran peserta didik dalam melaksanakan tindakan dan tes mencapai kehadiran siklus satu sebanyak 96,43\% secara total jumlah peserta didik 7 orang, dari pertemuan 1 (85,71\%) 1 orang sakit dan 6 orang hadir, pertemuan 2 hadir 7 orang (100\%), pertemuan 2 hadir 7 orang (100\%), berarti terdapat dukungan secara positif kehadiran peserta didik dalam melaksanakan tindakan dan tes, karena memenuhi standar persentase yang dicapai minimal $71 \%$.

Dengan demikian disimpulkan bahwa hasil penelitian model pembelajaran Make a Make siklus 1, belum dapat meningkatkan hasil belajar tema sumber energi siswa kelas IV SD Inpres Pancana kabupaten Barru, perlu dilanjutkan pemberian tindakan pada siklus 2.

\section{Siklus dua}

Hasil belajar siklus 2 adalah skor rerata 68,86 kategori kurang, dengan tuntas belajar $57,1 \%$ dari 4 orang subjek dan yang belum tuntas 3 orang subjek $42,9 \%$ dari total subjek 7 orang. Jika dibandingkan siklus 1 , skor rerata 67,86 kategori kurang, dengan tuntas belajar $57,1 \%$ dari 4 orang subjek dari total subjek 7 orang, meningkat rerata skor selisih 1,0\% kategori tidak meningkat tetap kurang siklus 2 dari siklus 1 . Kekurangan hasil belajar tema sumber energi peserta didik siklus 2 masih tetap sama siklus 1, yaitu: Kekurangan di siklus 2 diperbaiki 
di siklus 3 dengan upaya dipertegas lagi dalam dibimbing dengan baik dan diberi remedial yang belum tuntas 3 orang subjek. Kelebihannya adalah 4 orang subjek sudah tuntas belajar dipertahankan agar tidak menurun dan diupayakan agar dapat meningkat menjadi cukup atau di atas cukup.

Dukungan hasil penelitian kemampuan guru siklus 2, jumlah skor nilai yang dicapai 62 dengan 57,41\% kategori cukup, dengan skor total 108. Jika dibandingkan siklus 1 jumlah skor nilai yang dicapai 60 dengan 55,56\% kategori cukup, dengan skor total 108, terjadi peningkatan selisih 1,85\% kategori tidak meningkat tetap cukup siklus 2 dari siklus 1, belum terjadi perubahan secara positif. Selain itu, masih banyak kekurangan/kelebihan kemampuan guru yang ditemukan siklus 2 yaitu: Kelemahan siklus 2 hampir sama siklus 1, hanya saja skor yang dicapai berbeda, yaitu: Kekurangan siklus 2 diperbaiki di siklus 3 dan keleibhan diusahakan agar tidak menurun dan dapat meningkat menjadi sangat baik.

Dukungan hasil penelitian aktivitas belajar peserta didik siklus 2, jumlah skor nilai yang dicapai 456 dengan 60,32\%, dikategorikan cukup, dari total jumlah skor 756. Jika dibandingkan siklus 1, jumlah skor nilai yang dicapai 411 dengan 54,37\%, dikategorikan cukup, dari total jumlah skor 756, meningkat skor persentase selisih 5,95\%, kategori tidak meningkat tetap cukup siklus 2 dari siklus 1 , belum terjadi perubahan secara positif.

Masih banyak kekurangan/kelebihan aktivitas belajar peserta didik yang ditemukan siklus 2 yaitu: Kekurangan siklus 2 diperbaiki di siklus 3, kelebihannya diupayakan agar tidak menurun dan diusakan agar meningkat menjadi sangat baik disiklus 3 .

Refleksi tingkat kehadiran peserta didik dalam melaksanakan tindakan dan tes mencapai kehadiran siklus 2 sebanyak $100 \%$ secara total jumlah peserta didik 7 orang, dari pertemuan $1(100 \%) 7$ orang hadir semua, pertemuan 2 hadir 7 orang (100\%), pertemuan 3 hadir 7 orang $(100 \%)$, berarti terdapat dukungan secara positif kehadiran peserta didik dalam melaksanakan tindakan dan tes, karena memenuhi standar persentase yang dicapai minimal $71 \%$.

Dengan demikian disimpulkan bahwa hasil penelitian model pembelajaran Make a Make siklus 2, belum dapat meningkatkan hasil belajar tema sumber energi siswa kelas IV SD Inpres Pancana kabupaten Barru, perlu dilanjutkan pemberian tindakan pada siklus 3.

\section{Siklus tiga}

Hasil belajar siklus 3 adalah skor rerata 80,29 kategori cukup, dengan tuntas belajar $71,41 \%$ dari 5 orang subjek dan yang belum tuntas 2 orang subjek $28,6 \%$ dari total subjek 7 orang. Jika dibandingkan siklus 2, skor rerata 68,86 kategori kurang, dengan tuntas belajar $57,1 \%$ dari 4 orang subjek dari total subjek 7 orang, meningkat rerata skor selisih $11,43 \%$ kategori tidak meningkat tetap kurang siklus 3 dari siklus 2.

Kekurangan hasil belajar siklus 3 hampir tidak ditemukan lagi semua sudah menjadi kelebihan, hanya masih ada peserta didik yang memiliki nilai yang tidak mencapai KKM 70, tetapi tidak dilakukan perbaikan pada siklus selanjutnya, karena pemberian tindakan tidak berlanjut lagi pada siklus berikutnya, penelitian dihentikan hanya sampai pada siklus 3 , karena telah mencapai standar indikator keberhasilan tindakan utama penelitian.

Sedangkan perkembangan hasil penelitian, siklus 3 baru terdapat keberhasilan penelitian hasil belajar tema sumber energi siswa kelas IV SD Inpres Pancana kabupaten Barru, 
telah terjadi perubahan peningkatan secara positif, karena terdapat peningkatan siklus 3 ke siklus 2, dengan kualitas kategori siklus 3 menunjukkan minimal 70 atau minimal kategori cukup, dengan tuntas belajar minimal 71\% yang mendapat nilai KKM 70. Pada siklus 2 keberhasilan penelitian hasil belajar tema sumber energi siswa kelas IV SD Inpres Pancana kabupaten Barru, belum terjadi perubahan peningkatan secara positif, karena terdapat peningkatan rerata siklus 2 dari siklus 1, tetapi kategori tidak meningkat tetap kurang, dengan kualitas kategori siklus 2 belum menunjukkan minimal 70 atau minimal kategori cukup, dengan tuntas belajar minimal 71\% yang mendapat nilai KKM 70. Siklus 1 keberhasilan penelitian hasil belajar tema sumber energi siswa kelas IV SD Inpres Pancana kabupaten Barru, belum terjadi perubahan peningkatan secara positif, karena terdapat peningkatan rerata siklus 1 dari pra siklus, tetapi kategori tidak meningkat tetap kurang, dengan kualitas kategori siklus 1 belum menunjukkan minimal 70 atau minimal kategori cukup, dengan tuntas belajar minimal $71 \%$ yang mendapat nilai KKM 70.

Dukungan hasil penelitian kemampuan guru siklus 3, jumlah skor nilai yang dicapai 87 dengan $80,56 \%$ kategori baik, dengan skor total 108 . Dengan demikian, kemampuan guru dalam melaksanakan tindakan model pembelajaran Make a Match siklus 3 telah mencapai standar kualitas di atas $62,5 \%$ atau minimal baik menurut indikator keberhasilan dukungan penelitian ini. Jika dibandingkan siklus 2 jumlah skor nilai yang dicapai 62 dengan 57,41\% kategori cukup, dengan skor total 108, terjadi peningkatan selisih 23,15\% kategori meningkat baik siklus 3 dari cukup siklus 2, telah terjadi perubahan secara positif, karena mencapai peningkatan skor persentase dan kategori baik siklus 3 dari cukup siklus 2, dengan kualitas persentase dan kategori siklus 3 telah menunjukkan kualitas lebih besar $62,5 \%$ atau minimal kategori baik. Selain itu, tidak ditemukan lagi kekurangan rata-rata sudah menjadi kelebihan kemampuan guru siklus 3 dan berusaha untuk diperbaiki pada siklus selanjutnya.

Pada perkembangan hasil penelitian tingkat dukungan kemampuan guru, siklus 3 baru didukung keberhasilan penelitian kemampuan guru dalam mengelolah dan mengendalikan tindakan model pembelajaran Make a Match, terjadi perubahan secara positif, karena mencapai peningkatan skor persnetase siklus 3 dari siklus 2 kategori meningkat baik siklus 3 dari cukup dua, dengan kualitas persentase dan kategori siklus 3, telah menunjukkan kualitas lebih besar $62,5 \%$ atau minimal kategori baik. Siklus 2 belum didukung keberhasilan penelitian kemampuan guru, belum terjadi perubahan secara positif, karena mencapai peningkatan skor persnetase tetapi kategoti tetap cukup siklus 3 dari siklus 2, dengan kualitas persentase dan kategori siklus 2, belum menunjukkan kualitas lebih besar $62,5 \%$ atau minimal kategori baik.

Siklus 1 belum didukung keberhasilan penelitian kemampuan guru, belum terjadi perubahan secara positif, karena belum mencapai peningkatan skor persnetase siklus 1 dari pra siklus, kategori belum meningkat tetap cukup siklus 1 dari pra siklus, dengan kualitas persentase dan kategori siklus 1, belum menunjukkan kualitas lebih besar $62,5 \%$ atau minimal kategori baik.

Dukungan hasil penelitian aktivitas belajar peserta didik, siklus 3 jumlah skor nilai yang dicapai 590 dengan 78,04\%, dikategorikan baik, dari total jumlah skor 756. Jika dibandingkan siklus 2, jumlah skor nilai yang dicapai 456 dengan 60,32\%, dikategorikan cukup, dari total jumlah skor 756, meningkat skor persentase selisih 17,72\%, kategori meningkat baik siklus 3 dari cukup siklus 2, telah terjadi perubahan secara positif, karena mencapai peningkatan skor persentase dan kategori baik siklus 3 dari cukup siklus 2, dengan kualitas persentase dan kategori siklus 2 telah menunjukkan kualitas lebih besar $62,5 \%$ atau minimal kategori baik. 
Sedangkan perkembangan hasil penelitian tingkat dukungan aktivitas belajar peserta didik, siklus 3 baru didukung keberhasilan penelitian, terjadi perubahan secara positif, karena mencapai peningkatan skor persnetase siklus 3 dari siklus 2 kategori meningkat baik siklus 3 dari cukup dua, dengan kualitas persentase dan kategori siklus 3, telah menunjukkan kualitas lebih besar $62,5 \%$ atau minimal kategori baik. Siklus 2 belum didukung keberhasilan penelitian aktivitas, belum terjadi perubahan secara positif, karena mencapai peningkatan skor persnetase tetapi kategoti tetap cukup siklus 3 dari siklus 2, dengan kualitas persentase dan kategori siklus 2, belum menunjukkan kualitas lebih besar $62,5 \%$ atau minimal kategori baik. Siklus 1 belum didukung keberhasilan penelitian, belum terjadi perubahan secara positif, karena belum mencapai peningkatan skor persnetase siklus 1 dari pra siklus, kategori belum meningkat tetap cukup siklus 1 dari pra siklus, dengan kualitas persentase dan kategori siklus 1 , belum menunjukkan kualitas lebih besar $62,5 \%$ atau minimal kategori baik.

Refleksi tingkat kehadiran peserta didik dalam melaksanakan tindakan dan tes mencapai kehadiran siklus 3 sebanyak 100\% secara total jumlah peserta didik 7 orang, dari pertemuan 1 (100\%) 7 orang hadir semua, pertemuan 2 hadir 7 orang (100\%), pertemuan 3 hadir 7 orang (100\%), berarti terdapat dukungan secara positif kehadiran peserta didik dalam melaksanakan tindakan dan tes, karena memenuhi standar persentase yang dicapai minimal $71 \%$.

Dengan demikian disimpulkan bahwa: Hasil penelitian model pembelajaran Make a Make siklus 3, dapat meningkatkan hasil belajar tema sumber energi siswa kelas IV SD Inpres Pancana kabupaten Barru, sehingga tidak perlu dilanjutkan pemberian tindakan pada siklus selanjutnya dan dihentikan hanya sampai siklus 3.

\section{Kesimpulan}

Dari hasil penelitian ini dapat disimpulkan bahwa model pembelajaran Make a Match dapat meningkatkan hasil belajar tema sumber energi siswa kelas IV SD Inpres Pancana kabupaten Barru, meningkat skor rerata selisih 11,43\% meningkat kategori kurang menjadi cukup siklus 3 dari siklus 2 . Kemampuan guru meningkat skor persentase selisih 23,15\% dan kategori baik siklus 3 dari cukup siklus 2. Aktivitas peserta didik dalam melaksanakan model pembelajaran Make a Match. Meningkat skor persentase selisih 17,72\% dan kategori baik siklus 3 dari cukup siklus 2. Oleh karena itu disarankan untuk mempertahankan peningkatan secara positif hasil belajar tema sumber energi siswa kelas IV SD Inpres Pancana kabupaten Barru. Pertahankan perubahan secara positif kemampuan guru dalam mengelolah dan mengendalikan tindakan model pembelajaran Make a Match. Pertahankan perubahan secara positif aktivitas peserta didik dalam melaksanakan model pembelajaran Make a Match.

\section{Referensi}

Catharina, T. A. (2004). Psikologi Belajar. Semarang: IKIP Semarang Press.

Arikunto, S. (2007). Penelitian Tindakan Kelas. Jakarta : Bumi Aksara

Departemen Pendidikan Nasional. (2008). Kamus Umum Bahasa Indonesia. Edisi ke IV. Departemen Pendidikan Nasional. Jakarta: PT Gramedia Pustaka Utama.

Indah, O. D., Suhardi, S., \& Ramadhana, M. A. (2021). Pendampingan dan praktek pembuatan media pembelajaran bagi mahasiswa PGSD Universitas Cokroaminoto Palopo. Jurnal Abdimas Indonesia, 1(1), 12-17. Retrieved From https://www.dmijournals.org/jai/article/view/45 
Kementerian Pendidikan dan Kebudayaan Republik Indonesia. (2016). Panduan Penilaian untuk Sekolah Dasar. Jakarta: Kementerian Pendidikan dan Kebudayaan.

Kementerian Pendidikan dan Kebudayaan. (2017). Tema 2. Selalu Berhemat Energi Buku Tematik Terpadu Kurikulum 2013, Buku Guru SD/MI kelas IV. Revisi 2017. Jakarta: Kementerian Pendidikan dan Kebudayaan.

Kementerian Pendidikan dan Kebudayaan. (2017). Tema 2. Selalu Berhemat Energi Buku Tematik Terpadu Kurikulum 2013, Buku Siswa SD/MI Kelas IV. Revisi 2017. Jakarta: Kementerian Pendidikan dan Kebudayaan.

Milles \& Huberman. (1992). Analisis Data Kualitatif. Terjemahan Rohendi Rohidi. Jakarta: Universitas Indonesia

Purwanto, N. M. (2002). Psikologi Pendidikan. Bandung: Remaja Rosda Karya

Rusman. (2012). Model-model Pembelajaran Mengembangkan Profesionalisme Guru. Jakarta: Rajawali Pers

Sani, A. R. (2015). Pembelajaran Saintifik Utnuk Implementasi Kurikulum 2013. Jakarta: PT Bumi Aksara

Sugiarti, T. (1997). Penelitian Tindakan Kelas. Makalah Disajikan Dalam Pelatihan Peningkatan Kualifikasi Guru S1 PGSD. Universitas Jember

Sugiyono. (2016). Metode Penelitian Pendidikan. Bandung: Alfabeta

Widoyoko, E. P. S. (2012). Teknik Penyusunan Instrumen Penelitian. Yokyakarta: Pustaka Pelajar 